of life. General physiognomy, however typically Mediterranean, differs somewhat from that of the western shores of this Sea, as well as from that of its more northern parts; a number of species, for example, fishes, are peculiar to warm waters. Field work (hindered by war conditions) on various types of sea-bottom and sea-shore has revealed some noteworthy biocænosis. The predominance of Carddita sulcata, a lamellibranchiate molluscan, along the sandy beaches was already known; a peculiar association of Asterina and Chiton under the stones was now noted on rocky bottom in the harbour, with plenty of seaweeds; various other invertebrates were sharing the same habitat. Calcareous sponges, seaanemones (Anemonia sulcata), two species of Nemerteans, free and sedentary Polychæta, Bryozoa (among them Zoobotryon pellucidum) and Ascidians were found in the harbour of Rhodes city and its neighbourhoods. Actinia equina seems to be missing, but on the opposite shores of Anatolia a good number of fine specimens were found. In shallow water during summer Aplysia was plentiful and grazing among seaweeds; a good series of other Mollusca were collected, too. Among other species were Tethys leporina and two different Octopus. Colonies of Pyrosoma and some Hydromedusæ were the only pelagic animals that could be obtained. Twenty species of Echinoderms were gathered : among them Tethyaster, Ceramaster and Centrostephanus were quite common in rather deep water, more or less distant from the shore. Crustaceans were fairly abundant, and among the largest Malacostraca Squilla mantis, Scyllarides latus, Maia squinado, Calappa granulata and Dromia vulgaris do not appear to have been previously noticed, as well as Pagurus striatus, a common dweller of large shells of Cassis sulcosa and Murex trunculus.

Fishes were particularly looked for, and collected species amounted to 116 , of which six were Plagiostomia. Fishermen are few, and their work even in normal times is not a profitable one. The cause is to be found both in scarcity of plankton, that does not foster a rich fish-life, and in the nature of the seabottom, that forbids using some fishing technique otherwise advantageous. Ambiental conditions are unfavourable to fishes the life of which is largely dependent on development of continental shelf, as are Heterosomata, of which four species only were obtained. Shoals of migratory fishes (Scombroids, etc.) coming from the Black Sea or going there appear near Rhodes, but cannot support fisheries on an industrial scale. As a whole, these animals are much more numerous along the coasts of Asia Minor. Large sea-basses, mullets, red mullets, hakes and some sparoids were most frequently observed to be sold. This fish fauna shows a rather tropical character, that is stressed not only by such chiefly tropical families as Labroids and Carangoids or genera such as Sardinella and Sparisoma, but also by the presence of Red Sea immigrants. Only one of these, Siganus rivulatus, had previously been found in Aegean waters. Two other species may now be added-Hemirhamphus marginatus and Monacanthus setifer, the latter hitherto found only in Palestine. Apart from some species such as the small ray (Raia radula), that are more or less localized and the recognition of which is therefore interesting, four species, of which a single specimen was found in Rhodes, deserve particular mention. Lobotes surinamensis, a percoid, and Remilegia australis, a remora (sucking-fish), are tropical species of which we had but one Mediterranean record: the former was captured in Palermo (1875), the latter in Trieste (1881). Scyris alexandrinus, a form of deep-bodied carangoid, seems to be rare and until now was reporced only from North Africa and Syria. Gobius thori is a little goby of which only the type specimen, collected by the Thor near Tenedo (northern Aegean Sea) many years ago, was known.

All this material was unfortunately lost, but all notes and drawings were fortunately preserved, so that it has been possible to deal with it particularly in separate papers, that will appear-it is hopedas soon as printing difficulties will allow.

\section{RADIOCHEMISTRY IN BRITAIN}

\section{OPENING OF THE LONDONDERRY LABORATORY AT DURHAM}

$G^{R}$ REAT BRITAIN was in the forefront of original research on the chemistry of the radio-elements so long as Frederick Soddy, after his return from Montreal, was devoting his activities to this field. Much of the experimental material which led to his conception of isotopy was collected in his laboratories in Glasgow by A. Fleck; the first thorium-lead was prepared there and its atomic weight determined; and protoactinium was discovered by Soddy and Cranston in Aberdeen simultaneously with Hahn and Meitner in Berlin-Dahlem. No chemical laboratory in Great Britain, however, has followed up the tradition, so that from about 1918 on, the centres of radiochemical research were the Laboratoire Curie in Paris, and the Radium Department of the Kaiser Wilhelm Institut für Chemie at Dahlem, under Otto Hahn. How important their work was may be seen from the one fact that the discovery of the fission of uranium was an achievement to which the systematic study of the chemical products of the uranium irradiation was bound to lead, and to which the Paris laboratory had already come very close when Hahn and Strassmann's fundamental paper appeared. In Britain no corresponding work was undertaken, in spite of several physicists being greatly interested in the problem.

The need for a revival of radiochemistry was keenly felt during the Second World War, when the military and economic possibilities of the use of atomic energy had been recognized, and in Montreal a joint British--Canadian Government team, first under the directorship of Dr. H. Halban, and later under that of Prof. J. D. Cockeroft, did research work on uranium fission. The chemistry division of that team, built up during the years 1943-45 under Prof. F. A. Paneth, comprised finally more than thirty graduates, many of whom had been recruited in Britain.

It would have been deplorable if at the end of the War still no British university had shown interest in the study of radiochemistry. Fortunately, the University of Durham, with the support of the University Grants Committee, found ways and means of building a laboratory in which radiochemical specialists can carry out their researches and, at the same time, train young chemists in the particular techniques which will enable them to collaborate with the departments of nuclear physics in universities and Government establishments, and also with 
biologists interested in the use of radioactive tracers. The laboratory, designed by Dr. E. Glueckauf and Mr. L. Gradon, consists of two modest one-story buildings near the main Science Laboratories, one equipped for the chemical treatment of radioactive substances of low activities, the other for those emitting strong radiations.

This Laboratory-named after Lord Londonderry, chancellor of the University of Durham, who has personally contributed to the cost of its erection by a generous gift-was formally opened on June 4 by Viscount Portal of Hungerford, on whom the honorary degree of D.C.L. was conferred on this occasion. The ceremony was attended by Sir Wallace Akers, who during the War was director of the United Kingdom Government's atomic energy project; Dr. A. Fleck, Soddy's old collaborator; Dr. J. D. Cockcroft, now in charge of the Atomic Energy Research Establishment at Harwell ; Dr. J. Guéron, of the Commissariat de l'Energie Atomique in Paris; and many other well-known men of science. Lord Portal, who after his brilliant R.A.F. career is now directing the Government's efforts towards the peace-time utilization of atomic energy, replied with a speech which dealt largely with the relationship of British universities to the State. We print below some extracts from Lord Portal's address.

The practice of the universities of Great Britain in honouring members of the fighting services with degrees is, in my humble opinion, a very sound one, quite apart from the personal pleasure it gives to the recipients. It tends to emphasize one of the clearest lessons of the late War, that to secure the greatest possible efficiency the fighting services must call to their aid, in peace as well as in war, all the best talent in civil life, and make full use in many different ways of the type of brain-power that is to be found in the universities rather than in the fighting services in peace-time. The closer you can draw the bonds between the universities and the fighting services, the better for the country.

Much of the special scientific work done in the War by, or under the guidance of, members of the staff of the University of Durham was of great importance, directly or indirectly, to the fighting services. Under such distinguished men as Profs. Curtis, Riley and Wager, Drs. Valentine, Richardson and Varley, and Mr. Cragg, problems ranging from camouflage to the case-hardening of steel ; from air photography to agricultural pests; from hydrodynamics to the dehydration of food, were tackled with great success.

But to-day we are thinking mainly of radiochemistry, because this new Laboratory will be the first school in that subject to be formed in Great Britain, and the subject is one of very great importance if the peaceful uses of atomic energy are to be fully developed. It is good news that the school is to be under the charge of so eminent a man as Prof. F. A. Paneth, whose reputation extends far beyond this country and whom we were all delighted to see honoured recently with the fellowship of the Royal Society. $\mathrm{He}$ and some of his associates from this University, Drs. Chackett and Musgrave, and Mr. Martin and Mr. Morgan, did valuable work in Canada during the War, and there is much for them to do here in the future. For without skilled radiochemists in adequate numbers, we shall not be able to develop fully the use of the radioactive isotopes which we hope will be of such enormous benefit to future research in medicine, agriculture and industry generally.

I hupe you will not think it inappropriate if I conclude with one or two observations which are not strictly relevant to this occasion or to this University.

During the last year my work has brought me into close contact with many of the most eminent men of science in Great Britain. Perhaps it is a bit late for me to hope to make good the omissions of a classical education, but I can say with truth how enormously I respect these great men and the power and integrity of their brains, and how immensely helpful I have found their advice, even when I am unable to follow their calculations. In the course of my contact with them, and in reading what others have written, I have realized the depth of feeling which exists far and wide in the world of science about the responsibility of scientific men for the consequences of the discoveries they have made in the realm of nuclear fission.

Like the discovery of flying, this atom business is in many ways very awkward. I sympathize very much with the scientific men. It is perfectly true that the prospects for the good uses of atomic energy which are already foreseen, and for the discovery of others not yet foreseen, are at present gravely affected by international distrust and the resulting need for secrecy and strict Government control of the whole business. Secrecy is in itself a brake on progress, and if it has to be continued indefinitely it may well drive some good men in disgust to other lines of research where freedom is allowed and can do no harm. Government control, though it is absolutely necessary under present conditions, and perhaps always will be, means that the best brains in industry, particularly on the engineering and metallurgical sides which are every bit as important as the nuclearphysical side, are difficult to mobilize upon the problems of development.

No one could recognize all this more clearly than we officials who have to help to administer the law, but it really is no use pretending that conditions to-day are appropriate for the casting of all secrecy to the winds in the name of the freedom of science. What we can and will do is to try, consistently with our duty, to minimize the inconvenience caused by the restrictions and to interpret the will of Parliament in a liberal spirit.

I do not think that, on the long view, there need be any uneasiness about the British contribution to atomic energy, though the rate of progress is bound to be affected by the number of urgent things Britain has to tackle simultaneously at the present time. We may not have the volume of human and material resources that some other nations have, and the maintenance of a proper balance between research directed to the execution of a short-term programme and that required for the needs of long-term progress and training will always be a problem. But I do believe we have in Britain the quality of human genius which will before long put us in the very front rank. Quality is what we must bank on, and it is to the British universities that we must chiefly look to foster and maintain the quality of future generations of our scientists and engineers.

May I express the hope and belief of all who are here to-day that the Londonderry Laboratory will see long and useful service, and that the work done there will be outstanding in its contribution to the ultimate benefit of mankind. 